Studies EAJMBS October-December 2021, Vol. 1, No. 1, pp. 8-15

\title{
The Role of Internal Audit Function on Performance of Public Higher Learning Institutions in Tanzania: A Case of the Institute of Accountancy Arusha
}

\author{
Upendo Titus Mpocholwa* \\ ORCID: 0000-0002-7773-4008 \\ Department of Accounting and Finance \\ Institute of Accountancy Arusha, Tanzania \\ Valensi Kagoro \\ ORCID: 0000-0003-2533-7980 \\ Department of Accounting and Finance \\ Institute of Accountancy Arusha, Tanzania \\ *Corresponding Mail: upendompocholwa09@gmail.com

\begin{abstract}
Copyright resides with the author(s) in terms of the Creative Commons Attribution CC BY-NC 4.0. The users may copy, distribute, transmit and adapt the work, but must recognize the author(s) and the East African Journal of Management and Business Studies
\end{abstract}

\begin{abstract}
This study investigated on role of internal audit function on performance of public higher learning institutions in Tanzania using the descriptive correlational design. From 306 staff members, 103 were selected through the simple random sampling and 83 filled and returned the questionnaires. Data was analyzed through descriptive statistics and regression analysis. The organization was found to be doing well in risk management and control mechanism aspects as part of the internal auditing function. There are adequate human and material resources for internal audit function. The internal audit staffs are qualified and the management supports the internal audit initiatives with ICT facilities and adequate budget. While risk management, control mechanism and availability of resources significantly predicted the organizational performance, governance process did not. Availability of resources for internal auditing was the best predictor for the organizational performance. It is therefore recommended that the organization should maintain the existing risk management strategies and regular presentation of risk management reports as such aspects contribute to the organizational performance. Since risk management, control mechanism and availability of resources are significant predictors for the organizational performance, there is need to keep improving the control mechanism and provide required resources for effective internal audit function.
\end{abstract}

Keywords: Internal audit, function, effectiveness, Risk management, control mechanism, performance.

How to cite: Mpocholwa, U. T, and Kagoro, V. (2021). The Role of Internal Audit Function on Performance of Public Higher Learning Institutions in Tanzania: A Case of the Institute of Accountancy Arusha. East African Journal of Management and Business Studies 1(1), 1-15. Doi: https://doi.org/10.46606/eajmbs2021v01i01.0002

\section{Introduction}

While internal audit function is important to public sectors, it is of great concern in higher learning institutions which Nwabueze (2011) in Francis and Imiete (2018) described as the industry that processes the manpower for socioeconomic, political and cultural development of any society. This study is justified by Siyaya, Epizitone, Jali and Olugbara (2021) who conducted a research on determinants of Internal Auditing Effectiveness and established that little research on internal audit has been conducted in the context of institutions of higher learning. The authors further argued that the most influential 
determinants of internal audit function can serve as a useful barometer to identify weaknesses and strengths. This can enable auditees to identify the extent to which value can be added to the local and global performance through automation, information and transformation effects.

Manyama (2020) conducted a study on effectiveness of internal audit function in Tanzania: A case study of Arusha District and established that internal audit function is not effective since top management, inadequate internal audit staff and lack of training on part of the internal audit staff do not adequately support the internal auditors. The study recommended the allocation of more resources to support recruitment of audit staff as well as support in periodic training. Urquia (2018) conducted a study on the effect of internal control system on financial performance in an institution of higher learning. The study found that management of the institution is committed to the control systems. It was also revealed that all revenues and expenditures were properly classified, assets of the University had increased and internal control system was positively correlated with financial performance. These findings suggest a relationship between internal audit function and the organizational performance.

Tulli (2016) studied on challenges facing internal auditing function in improving organizational performance in Tanzania, using a grounded theory strategy and revealed that structural limitations and capability deficiencies in terms of staffing, funding and lack of working facilities were key challenges that faced the audit department. Mahyoro and Kasoga (2021) investigated on attributes of the internal audit function and effectiveness of internal audit services: evidence from local government authorities in Tanzania and established that audit quality, organization setting and auditee attributes have a significant positive influence on the effectiveness of internal audit services in the country. Shio (2019) investigated on factors influencing the effectiveness of the functions of internal audit in the Tanzanian Ministry of Education, Science and Technology. The study established that the internal audit function is inadequately performed in public organizations due to the reason that internal auditors have a lot of responsibilities to fulfil than their capacity. The study recommended that management should allow the internal auditors to carry out the responsibilities in a free and independent manner in order to make appropriate judgments.

Furthermore, internal audit function has a significant contribution in strengthening internal control, hence becoming one of the key tools for corporate governance (Lerno, 2016). Salisu and Ransom (2014) pointed out that internal audit function provides information that is useful for managerial decision making, identification of organizational strengths and weaknesses, ensuring best management of resources, assisting social responsibility and minimizing organizational potential risks. Due to this, the Bank of Tanzania has made it mandatory for organizations to ensure effective internal audit functions (Ngopa, 2013). Furthermore, the Government of Tanzania has made laws and regulations that make it mandatory to have internal audit functions in all departments and institutions of the government. This is notable through the creation of the position of the Internal Auditor General (IAG) of the Government, which is independent to coordinate all internal audit activities both at the central and at the local government levels. Moreover, the National Board of Accountants and Auditors in Tanzania (NBAA) made a pronouncement on the adoption of International Professional Practices Framework (IPPF) issued by the Institution of internal Auditors (IIA) as a standard for internal audit in Tanzania (Mussa, 2015). This study focused on the role of internal audit function on the performance of higher learning institutions in Tanzania. The study was guided by the following research questions:

1. What is the effectiveness of the internal audit function in terms of (a) risk management, (b) control mechanism, (c) resources for internal auditing?

2. What is the perception of employees at the Institute of Accountancy Arusha on the performance of the organization?

3. Is there a significant effect of the internal audit function on the organizational performance at the Institute of Accountancy Arusha?

\section{Research Methodology}

\section{Research Design}

This study employed the descriptive correlational research design. The first two research questions 
were descriptive in nature while the third research question sought to establish the relationship between the independent and the dependent variables.

\section{Population and Sampling}

While there are five public higher learning institutions in Arusha, the Institute of Accountancy Arusha was selected through simple random sampling to represent others. The Institute had a total of 306 staff members from whom 103 were selected through the simple random sampling procedure. Of these, 83 (80.5\%) filled and returned the questionnaires. Males were 53 (63.9\%) while females were 26 (31.3\%). Those who did not disclose their gender were 4 (4.8\%). Therefore, majority were males. In terms of work experience, 50 (60\%) had the experience of five years or below, $5(6.0 \%)$ had the experience of 6 to 10 while 22 (26.5\%) had the experience of over ten years and 6 (7.2\%) did not disclose their working experience. Therefore, majority had the experience of five years or below. In terms of level of education, 3 (3.6\%) had secondary education, 33 (63.9\%) had tertiary education, $17(20.5 \%)$ had no formal education and $10(12.0 \%)$ did not disclose their education level. Therefore, majority had tertiary education. This could be due to the nature of the organization under investigation. Being an academic institution of higher learning, one would expect to find more employees with tertiary education level.

\section{Validity and Reliability}

Validity of the questionnaire was established through expert judgment whereby two research experts and one experienced auditor looked into the items in the questionnaire against the research questions and gave their inputs on what should be done to improve it prior to data collection. The comments given were taken into consideration and therefore the questionnaire was valid.

\begin{tabular}{lc}
\multicolumn{2}{c}{ Table 1: Reliability Test } \\
\hline Variable & $\begin{array}{c}\text { Cronbach } \\
\text { Alpha }\end{array}$ \\
\hline Risk Management & .858 \\
Control Mechanism & .876 \\
Availability of Resources & .790 \\
\hline
\end{tabular}

The researchers ensured the reliability of the questionnaire by calculating the Cronbach's Alpha through the Statistical package for Social Sciences (SPSS) as indicated in Table 1 . Since all the variables scored the Cronbach's Alpha of above 0.7 , the questionnaire was considered reliable for data collection.

\section{Statistical Treatment of Data}

Data was coded and analyzed using the Statistical Package for Social Sciences (SPSS). Particularly, frequencies and percentages were used to describe the demographic factors of respondents while mean scores and standard deviation were used to indicate the perception of respondents regarding the internal audit effectiveness and the organizational performance. Regression analysis, on the other hand, was used to establish the existing relationship between the independent and the dependent variables.

\section{Results and Discussion \\ Descriptive Analysis of Data}

The first two research questions described the perception of employees on the internal audit function and performance of the institution. Respondents were given items to indicate their agreement or disagreement under five options namely 5=strongly agree, 4=agree, 3=neutral and 1=strongly disagree. Interpretation of the mean scores was based on the following criteria: 1.00-1.49=strongly disagree, 1.502.49=disagree, $\quad 2.50-3.49=$ neutral, 3.504.49=agree and 4.50-5.00=strongly agree.

Research Question 1: What is the effectiveness of the internal audit function in terms of (a) risk management, (b) control mechanism, (c) resources for internal auditing?

The internal auditing function was measured through four sub variables namely risk management, control mechanism, governance process and resources for internal auditing. Each of these variables had some items in the questionnaire for respondents to indicate their agreement or disagreement.

\section{Risk Management}

The mean score for all items in table 2 ranged from 3.50 to 4.49 meaning to say, employees agreed with all the items regarding the risk management effectiveness. Particularly, they agreed that there are appropriate risk management strategies, risk management reports are prepared and presented at each quarter, the organization has an appropriate risk management policy and that the risk 
champions initiate the risk management process.

They also agreed that the risk management policy is adequate, risk management is done effectively, significant risks are escalated to the Audit Committee and governing Board and there is budget for risk management mitigations. Therefore, the organization under investigation was found doing well in risk management as part of the internal auditing function. According to Haseeb, Bibi, Qureshi and Khan (2014), risk management plays significant role in the accomplishment and completion of intended projects. Therefore, it is most likely that the higher learning institution under investigation can reach its intended goals and objectives due to optimized risk management strategies which actually avoid catastrophes that may interfere with development projects of the institution.

Table 2: Perception of Employees on Risk Management

\begin{tabular}{llccc}
\hline SN & \multicolumn{1}{c}{ Risk Management Effectiveness Items } & Mean & Std. Dev & Interpretation \\
1 & There are appropriate risk management strategies & 3.9268 & .82821 & Agree \\
2 & Risk management report are prepared and presented at each quarter & 3.8987 & .65231 & Agree \\
3 & The organization has an appropriate risk management policy & 3.8831 & .79429 & Agree \\
4 & The risk champions initiate the risk management process & 3.8434 & .78836 & Agree \\
5 & The risk management policy is adequate & 3.7901 & .80181 & Agree \\
6 & Risk management is done effectively & 3.7831 & .71650 & Agree \\
7 & Significant risks are escalated to Audit Committee and governing Board & 3.7831 & .92457 & Agree \\
8 & There is budget for risk management mitigations & 3.7407 & .87718 & Agree \\
\hline
\end{tabular}

Table 3: Perception of Employees on Control Mechanism

\begin{tabular}{llccc}
\hline SN & Control Mechanism Items & Mean & Std. Dev & Interpretation \\
\hline 1 & Quality Assurance Unit enhances the quality education & 4.2439 & .69497 & Agree \\
2 & There is proper recruitment policy for competent academic staff & 4.1687 & .65925 & Agree \\
3 & Academic staff are committed to provide quality education & 4.1687 & .60120 & Agree \\
4 & Management is committed to provide quality of education. & 4.1446 & .73472 & Agree \\
5 & There are adequacy of academic policies to ensure quality & 4.0964 & .61712 & Agree \\
6 & There is adequate quality assurance to promote education quality & 4.0732 & .64369 & Agree \\
7 & There is adequate internal control for academic performance & 4.0370 & .74907 & Agree \\
8 & Management monitors and evaluates organization activities & 4.0120 & .68954 & Agree \\
\hline
\end{tabular}

\section{Control Mechanism}

Control Mechanism was another ingredient under which the internal audit effectiveness was measured. Under this aspect, the mean score for all items in table 3 ranged between 3.50 and 4.49 manning to say, employees agreed with all the items regarding the control mechanism.

Particularly, they agreed that quality Assurance Unit enhances quality education, that there is proper recruitment policy for competent academic staff members. They also agreed that academic staff members are committed to provide quality education and that management is committed to provide quality of education. They further agreed that there are adequate academic policies to ensure quality, there is adequate quality assurance to promote education, there is adequate internal control for academic performance and that management monitors and evaluates the organizational activities. This indicates that the organization did well in control mechanism as part of the internal audit function. According to Zhang (2018), internal control plays an important role in corporate governance, and it has an important impact on to the organization in question.

\section{Resources for Internal Auditing}

Resources for Internal Auditing had eight items to which employees had to indicate their agreement or disagreement as indicated in table 4 (p. 12). The mean score for all items in the table ranged between 3.50 and 4.49 manning to say, employees agreed with all the items regarding the resources for internal auditing. Particularly, they agreed that internal audit staffs are qualified, that there is effective communication for internal audit functions, that management supports the internal audit initiatives and that internal audit teams have satisfactory ICT services to fulfil their duties.

They also agreed that there is adequate budget allocated for internal audit, that internal audit teams have supportive working tools, that 
internal audit teams have conducive working environments and that there is adequate number of staff who deal with internal audit. This means that the organization under investigation did well in terms of resources for internal audit as part of the internal audit function. These results are commendable because scope of work by internal audit is affected by availability of resources (Asiedu \& Deffor, 2017). The established availability of resources can enhance the internal audit function which may result to the optimized organizational performance.

Table 4: Perception of Employees on Resources for Internal Auditing

\begin{tabular}{llccc}
\hline SN & \multicolumn{1}{c}{ Resources for Internal Auditing } & Mean & Std. Dev & Interpretation \\
\hline 1 & Internal audit staff are qualified & 4.2222 & .77460 & Agree \\
2 & There is effective communication in internal audit functions & 4.0482 & .81005 & Agree \\
3 & Management supports the internal audit initiatives & 3.9880 & .70700 & Agree \\
4 & Internal audit team have satisfactory ICT services to fulfil their duties & 3.9024 & .82566 & Agree \\
5 & There is adequate budget allocated for internal audit & 3.8902 & .84629 & Agree \\
6 & Internal audit team have supportive working tools & 3.8889 & .65192 & Agree \\
7 & Internal audit team have conducive working environments & 3.8025 & .81271 & Agree \\
8 & There is adequate number of staff who deal with internal audit & 3.7625 & .67961 & Agree \\
\hline
\end{tabular}

Table 5: Organizational Performance

\begin{tabular}{llllc}
\hline SN & \multicolumn{1}{c}{ Organizational Performance } & Mean & Std. Dev & Interpretation \\
\hline 1 & There is expansion of institution and academic programs & 4.5181 & .52641 & Agree \\
2 & There is achievement of the organizational strategic plan & 4.2169 & .60583 & Agree \\
3 & Staff development is effective at this institution & 4.0361 & .88958 & Agree \\
4 & The organization accomplishes its objectives as planned & 3.9756 & .71966 & Agree \\
5 & Staff social welfare is well managed & 3.9157 & .78406 & Agree \\
6 & There is a conducive working environment & 3.7952 & .93390 & Agree \\
\hline
\end{tabular}

Table 6: Model Summary

\begin{tabular}{|c|c|c|c|c|}
\hline Model & $\mathrm{R}$ & R Square & $\begin{array}{l}\text { Adjusted R } \\
\text { Square }\end{array}$ & $\begin{array}{l}\text { Std. Error of the } \\
\text { Estimate }\end{array}$ \\
\hline$\overline{1}$ & $.637^{\mathrm{a}}$ & .405 & .398 & .39471 \\
\hline 2 & $.695^{b}$ & .483 & .470 & .37044 \\
\hline 3 & $.729^{c}$ & .532 & .514 & .35458 \\
\hline
\end{tabular}

a. Predictors: (Constant), Resources

b. Predictors: (Constant), Resources, Control Mechanism

c. Predictors: (Constant), Resources, Control Mechanism, Risk

Management

Research Question 2: What is the perception of employees at the Institute of Accountancy Arusha on the performance of the organization?

Since the mean scores for employees on the organizational performance was between 3.50 and 4.49 , respondents agreed with all the items regarding the performance of the organization. They believed that there is expansion of institutional and academic programs, there is achievement of the organizational strategic plan and that staff development is effective. They also agreed that the organization accomplishes its objectives as planned, that the social welfare is well managed and that there is a conducive working environment.

Research Question 3: Is there a significant effect of the internal audit function on the organizational performance at the Institute of Accountancy Arusha?

This research question called for hypothesis testing to determine whether the independent variable (internal audit function) affects the dependent variable (performance of the organization). The research question called for hypothesis testing through regression analysis as reflected in table 6 to 9.The null hypothesis stated: there no significant effect of the internal audit function on the organizational performance at the Institute of Accountancy Arusha.

Results of the regression analysis are indicated in table $6,7,8$ and 9 . While table 6 shows that three independent variables (risk management, control mechanism and availability of resources) are significant predictors of the organizational 
performance, table 9 shows that governance process, with the sig of above.005, did not predict the organizational performance. Therefore, the null hypothesis is partly rejected since three out of four independent variables affect the dependent variable. While the multiple correlation coefficient (the relationship between organizational performance and the three independent variables) is .729 , the coefficient of multiple determination is .514 , which means $51.4 \%$ of the variance in the organizational performance is accounted for by availability of resources by $39.8 \%$, control mechanism by $7.2 \%$ ) and risk management by $4.4 \%$. Therefore, availability of resources for internal auditing was the best predictor for the organizational performance while governance processes did not account for the organizational performance. These results differ from what Chiggai (2016) found out in Kenya that risk management was not significant in predicting the organization performance. The results Chiggai, however, matches with the findings of this study that control environment had a significant co-efficient with the organizational performance and that the increase in control activities by a unit leads to increased organizational performance.

Table 7: ANOVA ${ }^{a}$

\begin{tabular}{|c|c|c|c|c|c|c|}
\hline & Model & Sum of Squares & df & Mean Square & $\mathbf{F}$ & Sig. \\
\hline \multirow[t]{3}{*}{1} & Regression & 8.603 & 1 & 8.603 & 55.218 & $.000^{b}$ \\
\hline & Residual & 12.620 & 81 & .156 & & \\
\hline & Total & 21.222 & 82 & & & \\
\hline \multirow[t]{3}{*}{2} & Regression & 10.244 & 2 & 5.122 & 37.327 & $.000^{\mathrm{C}}$ \\
\hline & Residual & 10.978 & 80 & .137 & & \\
\hline & Total & 21.222 & 82 & & & \\
\hline \multirow[t]{3}{*}{3} & Regression & 11.290 & 3 & 3.763 & 29.932 & $.000^{\mathrm{d}}$ \\
\hline & Residual & 9.933 & 79 & .126 & & \\
\hline & Total & 21.222 & 82 & & & \\
\hline
\end{tabular}
a. Dependent Variable: PERFORMANCE
b. Predictors: (Constant), RESOURCES
c. Predictors: (Constant), RESOURCES, CONTROL
d. Predictors: (Constant), RESOURCES, CONTROL, RISK

Table 8: COEFFICIENTS ${ }^{\mathrm{a}}$

\begin{tabular}{|c|c|c|c|c|c|c|}
\hline \multirow[b]{2}{*}{ Mode } & & \multicolumn{2}{|c|}{ Unstandardized Coefficients } & \multicolumn{2}{|c|}{$\begin{array}{l}\text { Standardized } \\
\text { Coefficients }\end{array}$} & \multirow[b]{2}{*}{ Sig. } \\
\hline & & $\mathrm{B}$ & Std. Error & Beta & $\mathrm{t}$ & \\
\hline \multirow[t]{2}{*}{1} & (Constant) & 1.487 & .351 & & 4.234 & .000 \\
\hline & RESOURCES & .659 & .089 & .637 & 7.431 & .000 \\
\hline \multirow[t]{3}{*}{2} & (Constant) & .792 & .386 & & 2.050 & .044 \\
\hline & RESOURCES & .473 & .099 & .458 & 4.786 & .000 \\
\hline & CONTROL & .346 & .100 & .331 & 3.459 & .001 \\
\hline \multirow[t]{4}{*}{3} & (Constant) & .601 & .375 & & 1.601 & .113 \\
\hline & RESOURCES & .303 & .112 & .293 & 2.718 & .008 \\
\hline & CONTROL & .305 & .097 & .291 & 3.148 & .002 \\
\hline & RISK & .269 & .093 & .291 & 2.884 & .005 \\
\hline
\end{tabular}

a. Dependent Variable: PERFORMANCE 


\begin{tabular}{|c|c|c|c|c|c|c|}
\hline Model & & Beta In & $\mathrm{t}$ & Sig. & $\begin{array}{c}\text { Partial } \\
\text { Correlation }\end{array}$ & $\begin{array}{c}\text { Collinearity } \\
\text { Statistics } \\
\text { Tolerance }\end{array}$ \\
\hline \multirow[t]{3}{*}{1} & Risk Management & $.338^{b}$ & 3.211 & .002 & .338 & .593 \\
\hline & Control Mechanism & $.331^{b}$ & 3.459 & .001 & .361 & .707 \\
\hline & Governance Process & $.189^{b}$ & 1.706 & .092 & .187 & .586 \\
\hline \multirow[t]{2}{*}{2} & Risk Management & $.291^{c}$ & 2.884 & .005 & .309 & .580 \\
\hline & Governance Process & $.173^{c}$ & 1.661 & .101 & .184 & .585 \\
\hline 3 & Governance Process & $.119^{d}$ & 1.163 & .248 & .131 & .561 \\
\hline
\end{tabular}

a. Dependent Variable: Performance

b. Predictors in the Model: (Constant), Resources

c. Predictors in the Model: (Constant), Resources, Control Mechanism

d. Predictors in the Model: (Constant), Resources, Control Mechanism, Risk Management

The results of the regression using the stepwise method indicated that the model explained $51.4 \%$ and that the model was a significant predictor of organizational Performance, $\mathrm{F}(3,79)=29.932, p<$ .001 . Availability of resources $(\beta=.303, p<.001)$, control mechanism $(\beta=.305, p<.001)$, and risk management $(\beta=.269, p<.001)$ contributed significantly to the model.

\section{Conclusions and Recommendations Conclusions}

The Arusha Institute of Accountancy did well in risk management aspects as part of the internal auditing function. This is due to the fact that there are appropriate risk management strategies, risk management reports are prepared and presented at each quarter, the organization has an appropriate risk management policy, and the risk champions initiate the risk management process. The organization did well in control mechanism as part of the internal auditing function. The governance process was efficient as employees believed that there is open communication channel between the staff and the management and the governing councils contributed in achieving the institutional objectives.

There are adequate human and material resources for internal audit function. The internal audit staffs are qualified and the management supports the internal audit initiatives with ICT facilities and adequate budget. While risk management, control mechanism and availability of resources significantly predicted the organizational performance, governance process did not. Availability of resources for internal auditing was the best predictor for the organizational performance.

\section{Recommendations}

The Arusha Institute of Accountancy should maintain the existing risk management strategies and regular presentation of risk management reports as such aspects contribute to effectiveness of the audit function. The organization should maintain the current control mechanism, appropriate recruitment procedures, provision of human and material resources and effective communication strategies as part of the internal audit function which will enhance the quality of education. Since risk management, control mechanism and availability of resources are significant predictors of the organizational performance, there is need to keep improving the control mechanism and provide required resources for effective internal audit function to be further realized.

\section{References}

Chiggai, H. I. (2016). Effect of Internal Audit Practices on Organization Performance: A Case of Regulatory Bodies in Kenya. MBA Unpublished Dissertation from KCA University, Kenya.

Francis, S., and Imiete, B. U. (2018). Internal Control System As A Mechanism for Effective Fund Management of Universities in Bayelsa State, Nigeria. Global Journal of Social Sciences 17(2018), 77-91.

Haseeb, M. Bibi, A., Qureshi, Q. A., and Khan, I. (2014). Analysis, Perception and Aspects of Risk Management in the Construction Sector of Pakistan. European Journal of Business and Management 6(20), 126138. 
Lerno, D. L. (2016). Relationship Between Internal Controls And Performance of County Government In Kenya. MBA Unpublished Dissertation, University of Nairobi, Kenya.

Mahyoro, A. K. and Kasoga, P. S. (2021). Attributes of the internal audit function and effectiveness of internal audit services: evidence from local government authorities in Tanzania. Managerial Auditing Journal 36(7), 999-1023.

Manyama, N. (2020).Effectiveness Of Internal Audit Function in Tanzania: A Case Study of Arusha District Council. Unpublished MBA Dissertation, Open University of Tanzania.

Mussa, S. J. (2015). Factors Contributing to Poor Performance of Internal Auditing in Public Sector: A Case Study of Zanzibar Electricity Corporation (ZECO). MSc Unpublished Dissertation, Mzumbe University, Tanzania.

Ngopa S.S. (2013). Factors influencing Internal Audit Operations in Electoral Bodies: An Empirical Analysis of Tanzania Electoral Commission. MBA Unpublished Dissertation, Open University of Tanzania.

Salisu, A. and Ransom, E. N. (2014). The Role of Modeling towards Impacting Quality Education. International Letters of Social and Humanistic Sciences (32), 54-61.
Shio, C. (2019). Factors Influencing the Effectiveness of the Functions of Internal Audit In Tanzania: A Case Of Ministry of Education, Science And Technology. MBA unpublished Dissertation.http://41.78. 64.2 5/bitstream/handle/20.500.1 2661/ 1905/SHIO\%2ODISSERTATION\%20final\%2 0\%20\%20submition\%20Final.pdf?sequenc $\mathrm{e}=1$ \&isAllowed=y.

Siyaya, M. C., Epizitone, A., Jali, L. F., and Olugbara, O. O. (2021). Determinants of Internal Auditing Effectiveness in A Public Higher Education Institution. Academy of Accounting and Financial Studies Journal 26(2) 1-18.

Tulli, M. M. (2016). Challenges facing internal audit function in improving organizational performance in local government authorities in Tanzania: a theory of wrestling for efficiency 25(1).

Urquia, L. G. M. (2018). Effects of internal control system on financial performance in an institution of higher learning. Journal of Fundamental and Applied Sciences 10(3S), 110-125.

Zhang, Y. (2018). Effectiveness of Internal Control, Financing Constraints and Corporate Value. European Journal of Business and Management 10(3), 100-107. 